資料：

\title{
茨城県に打ける周産期死亡率の 地域格差に関する検討
}

\author{
潤 田 嘉 朗
}

\begin{abstract}
高率な周産期死亡率の茨城県（昭和59年度周産期死亡率, 全国平均：8.7, 茨城県平均：10.9）で は，地域によってかなりな差がある。昭和54年から昭和58年までの市町村別平均周産期死亡率（以 下死亡率) は13.4, 県内 92 市町村の 万ち高率10か村の平均死亡率は 22.7 ; 低率 10 か所のそれは7.18 である。しかも, これら高率地域は県南東部 ( 6 か所), 県西部の一部 ( 1 か所) とに遍在しており, 低率地域は比較的県北部（6 か所）に遍在している。その理由については複雑で簡単に解明し得な いが，上記市町村地域を, 人口規模, 出生率, 死産率, 乳児死亡率, 新生児死亡率および早期新生 児死亡率等から解析してみた。特に施設分婏, 出生児体重等の点から県北と県南東部拈よび当院を 含む県南中部を中心に検討し, また県内重装備 NICU 設置医療機関が 3 か所と, そのベット数の点 からみてやや少ないことも, 茨城県の周産期死亡率の高い理由であると, 当院の NICU 設置前後の 死亡率改善成績 (19.8から9.7 改善) から推論するとともに, 高率な県南東部との関連性について も論じた。
\end{abstract}

(1)周産期死亡率 (2) NICU (3)出生率 (4)周産期死亡の因果関係 (5)新生児死亡率

\section{I は じめに}

茨城県の周産期死亡率 (以下死亡率) は全国平均か らみると, 常に悪く, ワースト・ッゥーの成績年度が 多い。昭和61年度では 8.3 と昭和 59 年度の 10.9 よりかな りよくなっているが, 全国平均も8.7より7.3と改善さ れている状況である。

日本産科婦人科学会茨城地方部会の茨城県周産期死 亡実態調査報告 (死亡児の母側からの疫学調査) ${ }^{6}$ をみ ると，県内92市町村でかなりな地域差があり，その理 由は決定的には解明し難いのであるが, 高率地域, 低 率地域掞よび市街地周辺地域の医療環境との関連から 特に考察してみた。周産期周辺の医療には, NICU が 欠くことができないのであるが，当院での NICU 設置 前後の死亡率の成績からも検討してみた。

\section{II 調查対象および方法}

1 ) 周産期死亡率打よび出生率, 乳児死亡率, 新生 児死亡率：昭和 54 年度より昭和 58 年までの 5 年間平均 率 (92市町村別母子衛生指標 $\left.{ }^{6}\right)$ 拈よび昭和 58 年度の茨

* 土浦協同病院産婦人科

（受付：1988年 2 月26日）
- : 産婦人科, 小児科併設病院所在地(昭和60年 3 月現在) 49 機関

$\odot:$ 茨城県新生児救急中核病院(昭和62年 7 月) 3 機関

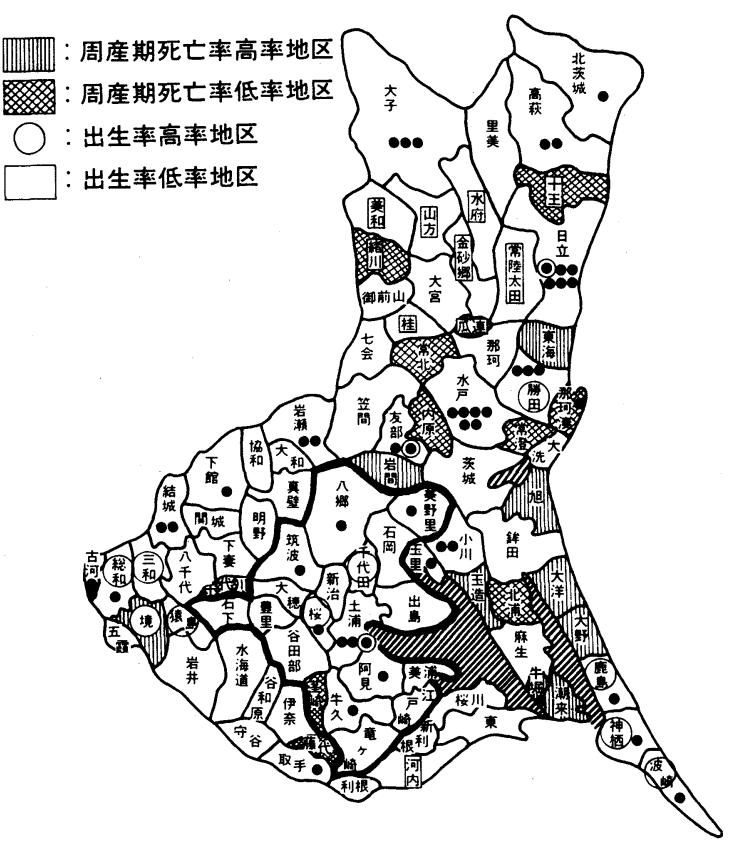

図 1.周産期死亡率及び出生率の高率, 低率地域 
城県衛生統計年報7より検討した。

2 ) 茨城県産婦人科医療機関の種類による出生率, 出生児体重, 死産率》秥よび当院の出産児統計拉よび 出産婦の住居範囲の解析も昭和 58 年度によった。

3 ) 当院の NICU 設置前後の死亡率の検討は, 昭和 50 年度から昭和 53 年 5 月までの期間と, 昭和 57 年より

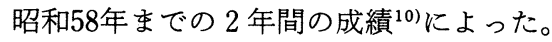

4）出産体重別周産期死亡数の検討結果は, 当院での 昭和 57 年より昭和 61 年までの 5 年間のものである。

\section{III 調查結果および成績}

1. 5 年間平均值衛生統計からの結果

1) 5 年間平均周産期死亡率の高低地域: (図 $-1^{6)}$, 表- 1)

昭和54 - 58年5年平均， 92 市町村別から検討すると， 図- 1 の縦線の地域が高率で, 最高率地は瓜連町の

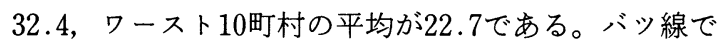

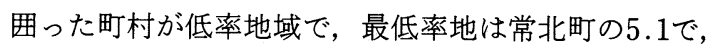

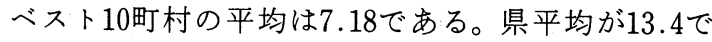
あった。

つまり, 県南東部に高率地（6か所）が多く，県北 に低率地（6 か所）が多いと格差が明瞭である。しか し, 県北にも高率地域が 3 か所, 県南東部にも低率地 が 1 か所認められていることも検討課題であろう。

また産婦人科, 小児科併設病院数も, その設備内容 等の規模は別にしても県北全周辺31市町村には24か所 と多く, 県南東部全周辺 13 町村は 7 か所々市町村数の 率からみればやや少ない。しかし出生数の規模（県北 全周辺：15,452名, 県南東部全周辺: 4,022 名, 58 年度) からみると病院数としては両者注ぼ同率である。ただ し NICU の充実した中核病院は県北には，2 か所あ り, 県南の東中西部を含めて, 当院の 1 か所の久であ る。この点からの解析を昭和 58 年度の統計資料から論 じてみたい。

表 1. 周産期死亡率の高率及び低率地域 ( 5 年平均)

\begin{tabular}{|c|c|c|c|c|c|c|c|c|}
\hline 地 域 市町村 & $\begin{array}{l}\text { 周 産 期 } \\
\text { 死亡率 } \\
\text { (出生千対) }\end{array}$ & 58年度 & $\begin{array}{l}\text { 出生 率 } \\
\text { (人口千対) }\end{array}$ & 58年度 & $\begin{array}{l}\text { 乳 児 } \\
\text { 死亡率 } \\
\text { (出生千対) }\end{array}$ & 58年度 & $\begin{array}{l}\text { 新 生 児 } \\
\text { 死亡率 } \\
\text { (出生千対) }\end{array}$ & 58年度 \\
\hline 県 北瓜連町 & 32.4 & 43.5 & 9.6 & 9.8 & 11.8 & 43.5 & 5.9 & 14.5 \\
\hline 県南東 大洋 村 & 25.6 & 8.0 & 13.7 & 12.8 & 19.6 & 8.0 & 15.0 & 8.0 \\
\hline 県南東 潮 来 町 & 23.5 & 32.0 & 14.4 & 13.6 & 17.3 & 12.8 & 13.0 & 12.8 \\
\hline 県南西 境 町 & 22.0 & 13.2 & 15.5 & 14.6 & 15.5 & 15.8 & 12.5 & 13.2 \\
\hline 県南東 玉 造 町 & 21.7 & 5.2 & 13.6 & 14.2 & 14.1 & 10.3 & 7.6 & 5.2 \\
\hline 県南東 牛 堀町 & 20.9 & 12.5 & 12.7 & 11.9 & 11.6 & 12.5 & 11.6 & 12.5 \\
\hline 県 北岩間町 & 20.5 & 11.1 & 12.0 & 11.5 & 10.8 & 11.1 & 7.5 & 5.6 \\
\hline 県 北 東海村 & 20.3 & 33.6 & 14.0 & 12.7 & 12.1 & 10.3 & 10.2 & 10.3 \\
\hline 県南東 大野村 & 20.1 & 44.3 & 14.2 & 12.2 & 19.0 & 44.3 & 16.7 & 44.3 \\
\hline 県南東 旭 & 20.1 & 12.0 & 15.2 & 15.6 & 17.5 & 6.0 & 8.7 & 6.0 \\
\hline 県 北内原町 & 9.2 & 10.9 & 12.2 & 12.6 & 4.6 & 5.5 & 2.3 & 0.0 \\
\hline 県 北 那珂凑市 & 9.1 & 10.5 & 11.9 & 11.5 & 5.5 & 13.1 & 4.0 & 10.5 \\
\hline 県南中 藤代 町 & 8.1 & 9.7 & 11.9 & 10.7 & 8.1 & 6.5 & 3.1 & 0.0 \\
\hline 県 北 緒川村 & 7.9 & 0.0 & 9.5 & 11.6 & 0.0 & 0.0 & 0.0 & 0.0 \\
\hline 県南中 茎 崎 町 & 7.8 & 4.3 & 13.9 & 11.1 & 4.7 & 8.4 & 2.4 & 0.0 \\
\hline 県南中 千代川村 & 6.6 & 8.5 & 13.9 & 13.5 & 5.0 & 8.5 & 3.3 & 8.5 \\
\hline 県 北十王町 & 6.6 & 0.0 & 11.0 & 10.5 & 3.3 & 0.0 & 1.7 & 0.0 \\
\hline 県 北 常澄村 & 6.1 & 7.7 & 13.4 & 13.0 & 4.6 & 7.7 & 4.6 & 7.7 \\
\hline 県南東 北 浦 村 & 5.3 & 12.3 & 13.7 & 14.5 & 9.3 & 12.6 & 4.0 & 6.3 \\
\hline 県 北 常 北町 & 5.1 & 24.2 & 11.0 & 11.5 & 6.8 & 16.1 & 1.7 & 8.1 \\
\hline 県平均 & 13.4 & 11.4 & 14.0 & 13.3 & 8.9 & 8.2 & 6.1 & 5.3 \\
\hline
\end{tabular}

(周産期死亡率高率10力所平均 : 22.7 
(20)

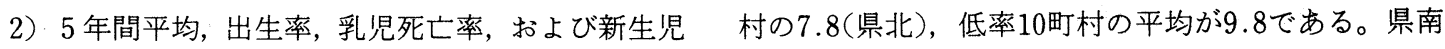
死亡率：（表- 1 , 表- 2 , 表- 3 , 図-1）

人口千対出生率を図-1でみると，○で囲った町村 および県西部に出生率が高い所が多く，県北には低い 所が多いといら結果であるが，これと，周産期死亡率 の高低との関連性については, 表- 2 上り出生率高率市 が, 高率地域で, 県平均が 14.0 , 最高率地は鹿島町の 町村と周産期死亡高率市町村が一致しているのは, 県 20.4 (県南東部), 高率 10 町村の平均が 16.9 である。 南西部の境町のみであり，また両者の低率が一致して

表 2．出生率の高率及び低率地域

\begin{tabular}{|c|c|c|c|c|c|c|c|}
\hline 地 域 & 高率市町村 & $\begin{array}{l}\text { 出生 率 } \\
\text { (人口千対) }\end{array}$ & & 地 域 & 低率市町村 & $\begin{array}{l}\text { 出 生 率 } \\
\text { (人口千対) }\end{array}$ & \\
\hline 県南東 & 鹿 島 町 & 20.4 & & 県 北 & 金砂郷村 & 7.8 & \\
\hline 県南中 & 千代田村 & 18.3 & & 県 北 & 水 府 村 & 8.6 & \\
\hline 県南東 & 神 栖 町 & 17.2 & & 県 北 & 緒 川 村 & 9.5 & $\Delta$ \\
\hline 県南西 & 三 和 町 & 16.6 & & 県 北 & 瓜 連 町 & 9.6 & 0 \\
\hline 県南中 & (旧) 桜 & 16.5 & & 県 北 & 山 方 町 & 10.0 & \\
\hline 県南東 & 波 崎 町 & 16.4 & & 県 北 & 常陸太田市 & 10.3 & \\
\hline 県南西 & 総 和 町 & 16.0 & & 県 北 & 桂 村 & 10.4 & \\
\hline 県 北 & 勝 田 市 & 16.0 & & 県南中 & 河 内 村 & 10.6 & \\
\hline 県南西 & 猿 島 町 & 15.7 & & 県 北 & 美 和 村 & 10.6 & \\
\hline 県南西 & 境 町 & 15.5 & O & 県 北 & 十王 町 & 11.0 & $\triangle$ \\
\hline
\end{tabular}

県平均 : 14.0

$\left(\begin{array}{l}\text { 高率10力所平均 }: 16.9 \\ \text { 低率10力所平均 }: 9.8\end{array}\right)$
母子衛生指標 (昭和 $54 \sim 58$ 年, 5 年平均)
$\bigcirc:$ 周産期死亡率高率地
$\triangle:$ 周産期死亡率低率地

表 3．新生児死亡率の高率及び低率地域

\begin{tabular}{|c|c|c|c|c|c|c|c|}
\hline 地 域 & 高率市町村 & $\begin{array}{l}\text { 新 生 児 } \\
\text { 死亡 率 } \\
\text { (出生千対) }\end{array}$ & & 地 域 & 低率市町村 & $\begin{array}{l}\text { 新 生 児 } \\
\text { 死亡率 } \\
\text { (出生千対) }\end{array}$ & \\
\hline 県南東 & 大 野 村 & 16.7 & 0 & 県 北 & 緒 川 村 & 0.0 & $\Delta$ \\
\hline 県南東 & 大 洋 村 & 15.0 & 0 & 県南中 & 谷和原村 & 0.0 & \\
\hline 県 北 & 里 美 村 & 14.4 & & 県 北 & 十王町 & 1.7 & $\triangle$ \\
\hline 県南東 & 潮 来 町 & 13.0 & 0 & 県 北 & 常 北 町 & 1.7 & $\Delta$ \\
\hline 県南西 & 町 & 12.5 & 0 & 県 北 & 内 原 町 & 2.3 & $\triangle$ \\
\hline 県 北 & 水 府 村 & 12.2 & & 県南中 & 茥 崎 町 & 2.4 & $\Delta$ \\
\hline 県南東 & 牛 堀 町 & 11.6 & 0 & 県南中 & 藤 代 町 & 3.1 & $\triangle$ \\
\hline 県 北 & 山方 町 & 10.8 & & 県南中 & 守 谷 町 & 3.2 & \\
\hline 県 北 & 東 海 村 & 10.2 & 0 & 県南中 & 千代川村 & 3.3 & $\triangle$ \\
\hline 県 北 & 美 和 村 & 9.9 & & 県 北 & 那 珂 町 & 3.3 & $\Delta$ \\
\hline
\end{tabular}

(高率10力所平均 : 12.6

低率10力所平均：2.1)

母子衛生指標（昭和 $54 \sim 58$ 年, 5 年平均)

0 : 周産期死亡率高率地

$\triangle:$ 周産期死亡率低率地 
いるのは県北の緒川村及び十王町のみで，県北の瓜連 町はむしろ, 周産期死亡率, 最高率地であり, 簡単に は結論づけられないが，いずれにしても，その関連性 については，それほど重要視しなくてよいのかも知れ ない(表-2)。

しかし，乳児死亡率および新生児死亡率が低い地域 は, 周産期死亡率が低い県北地域 ( 5 力所) と, 県南 中部（3か所）とに多い結果であり, 県南東部には低 率が一致する市町村は 1 か所もない。一方, 県南東部

（4 か所）及び県南西部（1 か所）の周産期死亡率の 高い地域（大洋村，大野村，牛堀町，潮来町，以上県 南東部，境町）が同時に新生児死亡率および乳児死亡 率が高いといら結果をみると，その地域には，特に注 目しないわけにはいかない。

また，県北にも新生児死亡率高率地が 5 か所あり， そのらち東海村のみが, 周産期死亡率高率地で一致し ている。この点については, 次の昭和 58 年度の衛生統 計によって検討したい(表-3)。

表一 1 よりみると, 新生児死亡率の高低地域と, 乳児 死亡率高低地域との関連は $1 \sim 2$ の例外 (瓜連町, 岩
間町，いずれも県北）はあるにしても，それぞれ一致 しているょうである。

3) 小 括

（1）周産期死亡率の高率地域は県南東部に多く, 県 北地域は低率地が遍在している。しかし県南東部地域 にも周産期死亡率低率市町村が少ないが一部認められ て招り，また県北地域にも周産期死亡率高率市町村が 3 か所あり, その点の考察が必要である。

(2) 周産期死亡率高低地域と出生率高低地域との関 連は多少あるにしても，考察するにあたっては，それ 注ど重要因子ではなさそうである。

（3）周産期死亡率高低地域と，新生児および乳児死 亡率高低地域との関連は，一部例外はあるにしても， 充分関連性があるものと思われる。

（4）医療環境の点からみると, 県北全周辺市町村に は産婦人科小児科併設病院が 24 か所と多く, 県南東部 全周辺町村には 7 か所と, 出生数の割合からみれば少 なくはないが, 重装備 NICU の充実した中核病院が県 北には 2 か所, 県南東部にはなく, 県南, 東中西部を 含めて，1か所のみといら差が著しい。

表 4 . 県北 (58年度)：周産期死亡率高率地及び低率地

\begin{tabular}{|c|c|c|c|c|c|c|c|c|c|c|c|c|c|c|c|c|}
\hline & \multirow{3}{*}{ 市町村 } & \multirow[t]{3}{*}{ 人口 } & \multirow{2}{*}{\multicolumn{3}{|c|}{$\begin{array}{l}\text { 出生数 乳児死亡数 新生児 } \\
\begin{array}{lll}\text { (率) } & \text { (率) } & \text { (率) }\end{array}\end{array}$}} & \multicolumn{2}{|r|}{ 死 } & \multicolumn{3}{|c|}{ 産 } & \multicolumn{3}{|c|}{ 周産期死亡 } & \multirow{3}{*}{ 率 } & \multirow{2}{*}{\multicolumn{2}{|c|}{$\begin{array}{l}28 \text { 週未渵の } \\
\text { 自然死産 } \\
\text { (自然死産一後期死産) }\end{array}$}} \\
\hline & & & & & & \multirow{2}{*}{\multicolumn{2}{|c|}{ 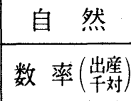 }} & \multirow{2}{*}{\multicolumn{2}{|c|}{$\frac{\text { 人 I }}{\text { 数 率 (出颜 })}$}} & \multirow{2}{*}{ 不 } & \multirow{2}{*}{ 総数 } & \multirow{2}{*}{$\begin{array}{l}\text { 後期 } \\
\text { 死産 }\end{array}$} & \multirow{2}{*}{$\begin{array}{l}\text { 早期新生 } \\
\text { 児死亡 }\end{array}$} & & & \\
\hline & & & \multicolumn{3}{|c|}{ (人口千対)（出生千対）(出生千対) } & & & & & & & & & & 数 菲 & 率(岸浐) \\
\hline & 茨城県総数 & $2,659,674$ & $\begin{array}{c}35,412 \\
(13.3)\end{array}$ & $\begin{array}{c}289 \\
(8.2)\end{array}$ & $\begin{array}{c}189 \\
(5.3)\end{array}$ & 913 & 24.8 & 535 & 14.5 & 5 & 405 & 252 & 153 & 11.4 & 661 & 17.9 \\
\hline \multirow{7}{*}{ 地 } & 内原町 & 14,439 & $\begin{array}{r}182 \\
(12.6)\end{array}$ & $\begin{array}{c}1 \\
(5.5)\end{array}$ & $\begin{array}{l}0 \\
(0)\end{array}$ & 5 & 25.9 & 6 & 31.1 & 0 & 2 & 2 & 0 & 10.9 & 3 & \\
\hline & 那珂湊市 & 33,172 & $\begin{array}{c}382 \\
(11.5)\end{array}$ & $\begin{array}{c}5 \\
(13.1)\end{array}$ & $\begin{array}{c}4 \\
(10.5)\end{array}$ & 5 & 12.6 & 10 & 25.2 & 0 & 4 & 1 & 3 & 10.5 & 4 & \\
\hline & 緒川村 & 5,238 & $\begin{array}{r}61 \\
(11.6)\end{array}$ & $\begin{array}{l}0 \\
(0)\end{array}$ & $\begin{array}{l}0 \\
(0)\end{array}$ & 1 & 15.6 & 2 & 31.3 & 0 & 0 & 0 & 0 & 0 & 1 & \\
\hline & 十王町 & 11,320 & $\begin{array}{c}119 \\
(10.5)\end{array}$ & $\begin{array}{l}0 \\
(0)\end{array}$ & $\begin{array}{l}0 \\
(0)\end{array}$ & 0 & 0 & 2 & 16.5 & 0 & 0 & 0 & 0 & 0 & 0 & \\
\hline & 常澄村 & 9,967 & $\begin{array}{r}130 \\
(13.0)\end{array}$ & $\begin{array}{c}1 \\
(7.7)\end{array}$ & $\begin{array}{c}1 \\
(7.7)\end{array}$ & 4 & 29.0 & 4 & 29.0 & 0 & 1 & 0 & 1 & 7.7 & 4 & \\
\hline & 岩間町 & 15,638 & $\begin{array}{r}180 \\
(11.5)\end{array}$ & $\begin{array}{c}2 \\
(11.1)\end{array}$ & $\begin{array}{c}1 \\
(5.6) \\
\end{array}$ & 5 & 26.6 & 1 & 5.3 & 0 & 2 & 2 & 0 & 11.1 & 3 & \\
\hline & 小率) $^{\text {計 }}$ & 89,774 & $\begin{array}{l}1,054 \\
(11.7)\end{array}$ & $\begin{array}{c}9 \\
(8.5) \\
\end{array}$ & $\begin{array}{c}6 \\
(5.7) \\
\end{array}$ & 20 & 18.2 & 25 & 22.7 & 0 & 9 & 5 & 4 & 8.5 & 15 & 13.6 \\
\hline \multirow{3}{*}{ 高 } & 東海村 & 30,500 & $\begin{array}{r}387 \\
(12.7)\end{array}$ & $\begin{array}{c}4 \\
(10.3)\end{array}$ & $\begin{array}{c}4 \\
(10.3)\end{array}$ & 15 & 36.9 & 5 & 12.3 & 0 & 13 & 9 & 4 & 33.6 & 6 & \\
\hline & 瓜連町 & 7,065 & $\begin{array}{r}69 \\
(9.8)\end{array}$ & $\begin{array}{c}3 \\
(43.5)\end{array}$ & $\begin{array}{c}1 \\
(14.5)\end{array}$ & 3 & 41.1 & 1 & 13.7 & 0 & 3 & 2 & 1 & 43.5 & 1 & \\
\hline & 常北町 & 10,765 & $\begin{array}{c}124 \\
(11.5)\end{array}$ & $\begin{array}{c}2 \\
(16.1)\end{array}$ & $\begin{array}{c}1 \\
(8.1) \\
\end{array}$ & 7 & 52.6 & 2 & 15.0 & 0 & 3 & 2 & 1 & 24.2 & 5 & \\
\hline \multirow{3}{*}{ 址 } & \begin{tabular}{|c|} 
小率) \\
計
\end{tabular} & 48,330 & $\begin{array}{r}580 \\
(12.0) \\
\end{array}$ & $\begin{array}{c}9 \\
(15.5) \\
\end{array}$ & $\begin{array}{c}6 \\
(10.3) \\
\end{array}$ & 25 & 40.8 & 8 & 13.1 & 0 & 19 & 13 & 6 & 32.8 & 12 & 19.6 \\
\hline & 合 計 & 138,104 & $\begin{array}{l}1,634 \\
(11.8)\end{array}$ & $\begin{array}{c}18 \\
(11.0)\end{array}$ & $\begin{array}{l}12 \\
(7.3)\end{array}$ & 45 & 26.3 & 33 & 19.3 & 0 & 28 & 18 & 10 & 17.1 & 27 & 15.8 \\
\hline & 率 & $5.2 \%$ & $4.6 \%$ & $6.2 \%$ & $6.3 \%$ & 4.99 & & 6.29 & & 0 & $6.9 \%$ & $7.1 \%$ & $\% \quad 6.5 \%$ & & 4.19 & \\
\hline
\end{tabular}


以上の考察点については, 昭和 58 年度の統計結果に よりたい。

\section{2 . 昭和 58 年度の衛生統計からの結果技よび当院の 成績}

5 年平均周産期死亡率高低を, 昭和 58 年度単年でみ ると（表-1）, 一部市町村に高低に变化が認められて いる。したがって昭和 58 年度単年の衛生統計から解析 するにあたっては，周産期死亡率高低地域を多少いれ か光, 県北と県南東部拉よび市街地周辺地域の代表と して, 当院を含む土浦保健所管轄（県南中部）を中心 にして, 死産率 (自然, 人工), 後期死産, 早期新生児 死亡, 満28週未満の自然死産率, 新生児死亡率, 乳児 死亡率および, 出生体重, 出産場所, 産婦人科病院お よび診療所数等の点から解析してみた。

昭和 58 年度の県平均周産期死亡率は11.4なので，そ の值の前後をそれぞれ，高低市町村の目安として，5 年平均高低地域を次のように修正地域別化した。

県北高率地域 ( 3 町村)：瓜連町, 東海村, 常北町 ( 5 年平均では低率地)

県北低率地域 (6 市町村)：緒川村, 十王町, 内原町, 常澄村, 那珂湊市, 岩間町 ( 5 年平均では高率地)

県南東部高率地域 ( 5 町村): 大野村, 潮来町, 牛堀 町, 旭村, 北浦町 (5 年平均では低率地)

県南東部低率地域 ( 2 町村)：大洋村, 玉造町（いず

\section{れも 5 年平均では高率地)}

県南中部地域 ( 5 市町村)：土浦市, 美浦村, 出島村, 新治村，阿見町（土浦保健所管轄）

以上の 3 地域それぞれの検討対照資料として，昭和 58 年度当院の出産児数, 死産児数, 早期新生児死亡数 および，それぞれの出産体重と，それぞれの死因， NICU 設置後の周産期死亡率の変化等について述べ る。

1）県北地域（9市町村）：（表-4，表-5）

(1) 出生率, 乳児死亡率, 新生児死亡率, 周産期死 亡率, 死産率

人口規模は県人口の $5.2 \%$ であり, 出生率は, 周産期 死亡高率地 (以下圖) でも, 同低率地 (以下低) でも, 県平均（13.3）よりやや低く, 圖が12.0, 园が11.7で 大差はないが, 乳児死亡率掞よび新生児死亡率は, 圖, 园いずれも県平均 $(8.2 ， 5.3)$ より高くなっている。

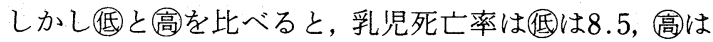
15.5 であり, 新生児死亡率も迈は 5.7 , 高は 10.3 といず れも䢑の方が低い。周産期死亡率の高低と, 乳児打よ び新生児死亡率高低との関連性があるようである。

周産期死亡率は䢑は8.5（県平均11.4）で低いのであ るが，満28週未満の自然死産率も13.6（県平均 $17.9 ）$ と低い。しかし人工死産率は 22.7 (県平均 14.5 ) と高 くなっている。圖の周産期死亡率は 32.8 と著しく高く,

表 5. 県北（58年度）：周産期死亡率高率地及び低率地

\begin{tabular}{|c|c|c|c|c|c|c|c|c|c|c|c|c|c|c|c|c|c|}
\hline \multirow{2}{*}{\multicolumn{2}{|c|}{ 市町村 }} & \multirow{2}{*}{\begin{tabular}{|l} 
出生児 \\
出生 \\
総数 \\
\end{tabular}} & \multicolumn{5}{|c|}{ 出生 児 体 重 } & \multicolumn{3}{|c|}{ 出生の立会者 } & \multicolumn{5}{|c|}{ 出 産 場 所 } & \multirow{2}{*}{\multicolumn{2}{|c|}{$\begin{array}{l}\text { 産妢人科 } \\
\text { 病院・診 診 } \\
\text { 療所の数 }\end{array}$}} \\
\hline & & & $\begin{array}{l}1,000 \mathrm{~g} \\
\text { 未 満 }\end{array}$ & $\begin{array}{l}1,000 \sim \\
1,499 \mathrm{~g}\end{array}$ & $\begin{array}{l}1,500 \sim \\
1,999 \mathrm{~g}\end{array}$ & $\begin{array}{l}2,000 \sim \\
2,500 \mathrm{~g}\end{array}$ & $\begin{array}{l}2,501 \mathrm{~g} \\
\text { 以 上 }\end{array}$ & 医師 & 助産婦 & その他 & 病院 & 診療所 & 助産所 & 自宅 & その他 & & \\
\hline & $\begin{array}{l}\text { 茨城県 } \\
\text { 総数 (率) }\end{array}$ & 35,412 & $\begin{array}{c}39 \\
(0.1 \%) \\
\end{array}$ & $\begin{array}{l}119 \\
(0.3 \%) \\
\end{array}$ & $\begin{array}{l}294 \\
(0.8 \%) \\
\end{array}$ & $\begin{array}{l}1,609 \\
(4.5 \%) \\
\end{array}$ & $\begin{array}{l}33,351 \\
(94.3 \%) \\
\end{array}$ & $\begin{array}{l}34,310 \\
(96.9 \%) \\
\end{array}$ & $\begin{array}{l}1,096 \\
(3.1 \%) \\
\end{array}$ & 620 & $\begin{array}{l}11,719 \\
(33.0 \%)\end{array}$ & $\begin{array}{l}14,260 \\
(40.3 \%) \\
\end{array}$ & $\begin{array}{c}915 \\
(2.6 \%) \\
\end{array}$ & 95 & 25 & \begin{tabular}{|l|} 
病 \\
院 \\
\end{tabular} & $\begin{array}{l}\text { 診 } \\
\text { 療 } \\
\text { 所 }\end{array}$ \\
\hline \multirow{5}{*}{ 低 } & 内原町 & 182 & 0 & 1 & 2 & 10 & 169 & 181 & 1 & 0 & 132 & 49 & 1 & 0 & 0 & 0 & 0 \\
\hline & 那珂湊市 & 382 & 0 & 1 & 2 & 17 & 362 & 382 & 0 & 0 & 275 & 107 & 0 & 0 & 0 & 0 & 2 \\
\hline & 緒川村 & 61 & 0 & 1 & 2 & 4 & 54 & 61 & 0 & 0 & 19 & 41 & 0 & 1 & 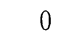 & 0 & 0 \\
\hline & 十王町 & 119 & 0 & 0 & 1 & 4 & 114 & 81 & 38 & 0 & 50 & 34 & 35 & 0 & 0 & 0 & 0 \\
\hline & 常澄村 & 130 & 0 & 0 & 1 & 7 & 122 & 130 & 0 & 0 & 57 & 73 & 0 & 0 & 0 & 0 & 1 \\
\hline \multirow[t]{2}{*}{ 地 } & 岩間町 & 180 & 1 & 0 & 1 & 16 & 162 & 178 & 2 & 0 & 162 & 16 & 0 & 2 & 0 & 0 & 0 \\
\hline & $\begin{array}{c}\text { 小 計 } \\
\text { (率) }\end{array}$ & 1,054 & $\begin{array}{c}1 \\
(0.1 \%)\end{array}$ & $\begin{array}{c}3 \\
(0.3 \%) \\
\end{array}$ & $\begin{array}{c}9 \\
(0.9 \%) \\
\end{array}$ & $\begin{array}{r}58 \\
(5.4 \%) \\
\end{array}$ & $\begin{array}{r}983 \\
(98.3 \%) \\
\end{array}$ & $\begin{array}{c}1,013 \\
(96.1 \%)\end{array}$ & $\begin{array}{c}41 \\
(3.9 \%) \\
\end{array}$ & 0 & $\begin{array}{r}695 \\
(69.9 \%)\end{array}$ & $\begin{array}{r}320 \\
(30.4 \%) \\
\end{array}$ & $\begin{array}{c}36 \\
(3.4 \%)\end{array}$ & 3 & 0 & 0 & 3 \\
\hline \multirow{2}{*}{ 高 } & 東海村 & 387 & 1 & 2 & 4 & 12 & 368 & 384 & 3 & 0 & 216 & 169 & 1 & 1 & 0 & 0 & 1 \\
\hline & 瓜連町 & 69 & 1 & 0 & 0 & 2 & 66 & 69 & 0 & 0 & 53 & 16 & 0 & 0 & 0 & 1 & 0 \\
\hline 率 & 常北町 & 124 & 0 & 2 & 0 & 9 & 113 & 124 & 0 & 0 & 69 & 55 & 0 & 0 & 0 & 2 & 0 \\
\hline \multirow[t]{2}{*}{ 地 } & $\begin{array}{c}\text { 小 } \begin{array}{c}\text { 計 } \\
\text { (率) }\end{array} \\
\end{array}$ & 580 & $\begin{array}{c}2 \\
(0.4 \%) \\
\end{array}$ & $\begin{array}{c}4 \\
(0.7 \%) \\
\end{array}$ & $\begin{array}{c}4 \\
(0.7 \%) \\
\end{array}$ & $\begin{array}{r}23 \\
(3.9 \%) \\
\end{array}$ & $\begin{array}{r}547 \\
(94.3 \%) \\
\end{array}$ & $\begin{array}{r}577 \\
(99.5 \%) \\
\end{array}$ & $\begin{array}{r}3 \\
(0.5 \%) \\
\end{array}$ & 0 & $\begin{array}{r}338 \\
(58.3 \%) \\
\end{array}$ & $\begin{array}{r}240 \\
(41.4 \%) \\
\end{array}$ & $\begin{array}{c}1 \\
(0.2 \%) \\
\end{array}$ & 1 & 0 & 3 & 1 \\
\hline & $\begin{array}{c}\text { 合 計 } \\
\text { 率 }\end{array}$ & $\begin{array}{l}1,634 \\
4.6 \%\end{array}$ & $\begin{array}{c}3 \\
0.2 \%\end{array}$ & $\begin{array}{c}7 \\
0.4 \%\end{array}$ & $\begin{array}{c}13 \\
0.8 \%\end{array}$ & $\begin{array}{r}81 \\
5.0 \%\end{array}$ & $\begin{array}{r}1,530 \\
93.6 \%\end{array}$ & $\begin{array}{r}1,590 \\
97.3 \%\end{array}$ & $\begin{array}{r}44 \\
2.7 \%\end{array}$ & $\begin{array}{l}0 \\
0\end{array}$ & $\begin{array}{r}1,033 \\
63.2 \%\end{array}$ & $\begin{array}{r}560 \\
34.3 \%\end{array}$ & $\begin{array}{c}37 \\
2.3 \%\end{array}$ & $\begin{array}{c}4 \\
0.2 \%\end{array}$ & 0 & 3 & 4 \\
\hline
\end{tabular}


満28週未満の自然死産率も19.6 と県平均より高い。そ れに反して, 人工死産率は 13.1 と県平均 (14.5) より やや低くなっている（表-4）。

（2）出生児体重，出産場所

超未熟児または極小未熟児がどれほど出生したかを 体重別からみると, 圖および园いずれも県平均レベル の出生未熟児がおり, 特に圖には, 超未熟児の生存が 認められていることは, 周産期死亡率高率地区である こととあわせて，検討課題であろう。

出産場所は県平均では病院出生 $33.0 \%$, 診療所出生 $40.3 \%$ と診療所出生が多く, 助産所出生は $2.6 \%$ で検討 対照外とする。圖および低いずれも病院出生の方が多 く, 特に目では病院出生 $69.9 \%$ に及てでいる。また, 助産所出生は圖䢑平均して $2.3 \%$ でる。しかし, その 市町村地域にある病院は 0 で, 診療所は 3 か所である 所から，そのほとんどは，県北市街地区(日立，水戸， 勝田市) の出生なのであろう。

内科, 小児科併設診療所は, 迈では13か所, 高では 7 か所と市町村数の率からみれば同率ではあるが，あ るいはその数の場所的関係の差とか, 地域の衛生環境, 母親の育児知識を含めた生活家庭環境等が乳児死亡率 の差に影響をあたえているのかも知れない。
圖地域は, 病院 3 力所（産婦人科, 小児科併設病院 はない。), 診療所 1 か所が存在しているが, 超未熟児 が出生しているところからみると, やはり出産場所の 多くは, その地域の病院ではなく, 特に日立市之水戸 市の中間にある東海村には病院は 0 なので, 恐らく県 北中核病院等の出生なのであろう。瓜連町, 常北町も 病院出生の方が多いのであるが, 東海村も含めて, 交 通の便等, 地理的な問題との関連があるのかも知れな い(表- 5 )。

(3) 小括および考察

a ）圖，低いずれも出生率と周産期死亡率高低との 関係は，それ注どなさそうである。

b ) 圖, 园いずれも周産期死亡率高低と, 乳児拉上 び新生児死亡率高低との関連はあるようである。

c ）圖，目いずれ子病院出生の方が多く（特に低が 著しい), 未熟児出生の頻度からみても, 圖, 圆間 に大差はない。病院出産のみが，死亡率を少なく 寸る根拠ではないが, 設備面, 医療従事者数の面 からすれば，多少の関連があるかも知れない。な ぜ圆地域の周産期死亡率が高いのかは不明である が，医療環境との地理的，場所的な関係があるの かも知れないし，周産期死亡児の体重, 死因等お

表 6 . 県南東部（58年度）：周産期死亡率高率地及び低率地

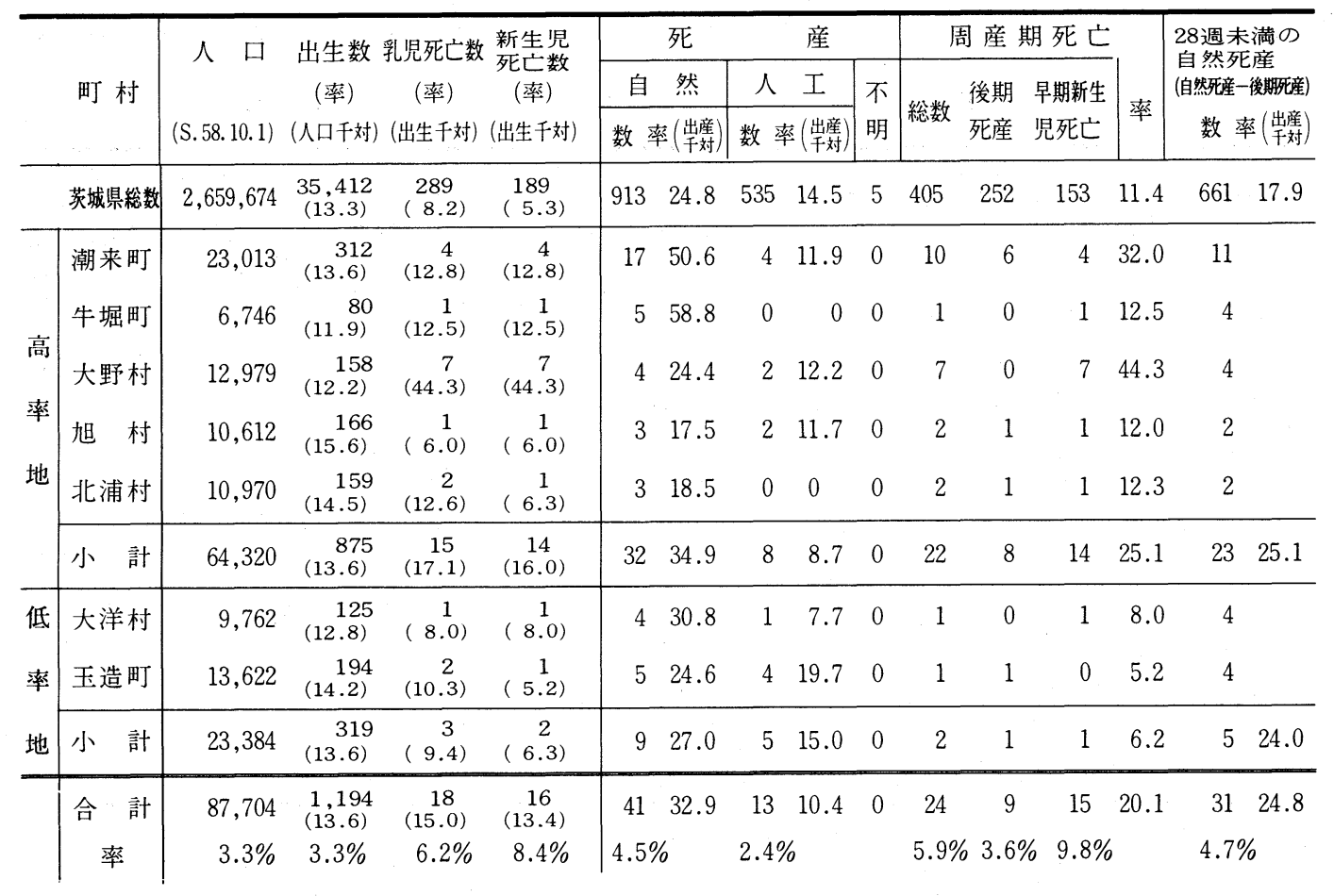


よびその母親の疫学的調査等によらないと解明し 難いと思われる。

d）人工死産率は, 法的なものと，法によらないも のとが含まれており，優性保護法によるものが圧 倒的に多いのであるが(茨城県総数535件，法によ るもの：97.2\%), 無届のものがあるので,この統 計より実際は相当多いものとしたらえで考えねば ならない。四が高より 22.7 と多いことは，この地 域の家庭経済生活との関連の一因子として考えて よいかも知れない。

e ）満28週未満の自然死産率も, 高が県平均より高 く, 低が低い。やはり周産期死亡率高低と一致し ていることは, NICUの問題も含めた医療環境と の関連として考えたい。

f ）県北全周辺市町村には，産婦人科，小児科併設 病院数が24か所あり，そのうち重装備 NICU 中核 病院は 2 か所ある。軽装備 NICUを所有している 病院も最低でも 6 か所は存在している。県南東部 に比べて，非常に恵まれている医療環境といえよ $\zeta$ 。

2）県南東部地域（7町村）：（表- 6 ，表-7）

（1）出生率，乳児死亡率，新生览死亡率，周産期死 亡率, 死産率

人口規模は $3.3 \%$ 。出生率は高：13.6, 圆 13.6 と県平 均 (13.3) よりやや高い。乳児死亡率执よび新生児死 亡率は，圖：17.1，16.0と県北よりきわめて高く，低
でも $9.4 ， 6.3$ と県平均 $(8.2,5.3)$ よりやや高い。周 産期死亡率は圖：25.1 と高く，満28週未満の自然死産 率も25.1ときわめて高い。䢑の周産期死亡率は6.2 とき わめて低いのであるが，出生数が少ないことを考慮し なくてはならないし，満28週末満の自然死産率が 24.0 と高と同様に高くなっている点に注目すべきであろ 5。それに反して，人工死産率は圖では 8.7 ときめて 低く，䢑でも，15.0と県平均（14.5）なみである（表 -6 )。

\section{（2）出生児体重, 出産場所}

超末熟児または極小未熟児の出生率は，高では県平 均レベルか, やや上回っている。圆では出生数が少な いので何とも言えない。

出産場所は，病院出産が，圖では47.5\%，氐では $53.6 \%$ と県平均 $(33.0 \%)$ より多いのであるが，県北 よりは少ない。その市町村地域の病院数は圖は 3 か所, 䢑は 1 か所（産婦人科，小児科併設はそれぞれに 1 か 所）診療所は圖は 1 か所，低も 1 か所となっている。 したがって，高，䢑いずれも，県北と同じように，そ の地区の病院出生より, 鹿島, 波崎地区の病院出生が 多いのであろ う。助産所出生は圖园平均して $3.1 \%$ と なっている。

また，内科，小児科併設診療所は圖は 9 か所，低は 3 か所となっており，町村数の率からみれば，圖の方 がやや多い結果である。にもかかわらず圖の乳児およ び新生児死亡率が高いのは，低も含めて，その地域の

表 7 . 県南東部 (58年度)：周産期死亡率高率地及び低率地

\begin{tabular}{|c|c|c|c|c|c|c|c|c|c|c|c|c|c|c|c|c|c|}
\hline \multirow{2}{*}{\multicolumn{2}{|c|}{ 町村 }} & \multirow{2}{*}{\begin{tabular}{|l|} 
出生児 \\
出生 \\
総 数
\end{tabular}} & \multicolumn{5}{|c|}{ 出 生 児 体 重 } & \multicolumn{3}{|c|}{ 出生の立会者 } & \multicolumn{5}{|c|}{ 出 産 場 所 } & \multirow{2}{*}{\multicolumn{2}{|c|}{$\begin{array}{l}\text { 産婦人科 } \\
\text { 病院・診 } \\
\text { 療所の数 }\end{array}$}} \\
\hline & & & $\begin{array}{l}1,000 \mathrm{~g} \\
\text { 末 満 }\end{array}$ & $\begin{array}{l}1,000 \sim \\
1,499 \mathrm{~g}\end{array}$ & $\begin{array}{l}1,500- \\
1,999 \mathrm{~g}\end{array}$ & $\begin{array}{l}2,000 \sim \\
2,500 \mathrm{~g}\end{array}$ & \begin{tabular}{|l}
$2,500 \mathrm{~g}$ \\
以 上
\end{tabular} & 医師 & 助産婦 & その他 & 病院 & 診療所 & 助産所 & 自宅 & その他 & & \\
\hline & $\begin{array}{l}\text { 茨城県 } \\
\text { 総数 (率) }\end{array}$ & 35,412 & $\begin{array}{c}39 \\
(0.1 \%) \\
\end{array}$ & $\begin{array}{c}119 \\
(0.3 \%)\end{array}$ & $\begin{array}{c}294 \\
(0.8 \%)\end{array}$ & $\begin{array}{l}1,609 \\
(4.5 \%) \\
\end{array}$ & $\begin{array}{l}33,351 \\
(94.3 \%) \\
\end{array}$ & $\begin{array}{l}34,310 \\
(96.9 \%) \\
\end{array}$ & $\begin{array}{l}1,096 \\
(3.1 \%) \\
\end{array}$ & 620 & $\begin{array}{l}11,719 \\
(33.0 \%) \\
\end{array}$ & $\begin{array}{l}14,260 \\
(40.3 \%) \\
\end{array}$ & $\begin{array}{l}915 \\
(2.6 \%) \\
\end{array}$ & 95 & 25 & \begin{tabular}{|l} 
病 \\
院 \\
\end{tabular} & $\begin{array}{l}\text { 診 } \\
\text { 療 } \\
\text { 所 }\end{array}$ \\
\hline \multirow{3}{*}{ 高 } & 潮来町 & 312 & 0 & 2 & 1 & 17 & 292 & 311 & 1 & 0 & 170 & 141 & 1 & 0 & 0 & 2 & 1 \\
\hline & 牛堀町 & 80 & 1 & 0 & 0 & 5 & 74 & 80 & 0 & 0 & 45 & 35 & 0 & 0 & 0 & 1 & 0 \\
\hline & 大野村 & 158 & 0 & 1 & 3 & 7 & 147 & 152 & 5 & 1 & 45 & 108 & 1 & 3 & 1 & 0 & 0 \\
\hline \multirow[t]{3}{*}{ 率 } & 旭 村 & 166 & 0 & 0 & 4 & 5 & 157 & 150 & 16 & 0 & 81 & 69 & 16 & 0 & 0 & 0 & 0 \\
\hline & 北浦村 & 159 & 0 & 0 & 4 & 8 & 147 & 149 & 10 & 0 & 60 & 89 & 10 & 0 & 0 & 0 & 0 \\
\hline & $\mid \begin{array}{c}\text { 小 }{ }^{\text {計 }} \\
\text { (率) }\end{array}$ & 875 & $\begin{array}{c}1 \\
(0.2 \%)\end{array}$ & $\begin{array}{c}3 \\
(0.3 \%)\end{array}$ & $\begin{array}{c}12 \\
(1.4 \%)\end{array}$ & $\begin{array}{r}42 \\
(4.8 \%)\end{array}$ & $\begin{array}{r}817 \\
(93.3 \%)\end{array}$ & $\begin{array}{r}842 \\
(96.2 \%)\end{array}$ & $\begin{array}{r}32 \\
(3.7 \%)\end{array}$ & 1 & $\begin{array}{r}401 \\
(47.5 \%)\end{array}$ & $\begin{array}{r}442 \\
(50.5 \%)\end{array}$ & $\begin{array}{c}28 \\
(3.2 \%)\end{array}$ & 3 & 1 & 3 & 1 \\
\hline \multirow[t]{2}{*}{ 低 } & 大洋村 & 125 & 0 & 0 & 2 & 8 & 115 & 122 & 3 & 0 & 45 & 77 & 3 & 0 & 0 & 0 & 1 \\
\hline & 玉造町 & 194 & 0 & 0 & 1 & 12 & 181 & 188 & 6 & 0 & 126 & 62 & 6 & 0 & 0 & 1 & 0 \\
\hline 地 & $\begin{array}{c}\text { 小率) } \\
\text { 計 }\end{array}$ & 319 & 0 & 0 & $\begin{array}{c}3 \\
(0.9 \%)\end{array}$ & $\begin{array}{r}20 \\
(6.3 \%)\end{array}$ & $\begin{array}{r}296 \\
(92.8 \%)\end{array}$ & $\begin{array}{r}310 \\
(97.1 \%)\end{array}$ & $\begin{array}{r}9 \\
(2.9 \%)\end{array}$ & 0 & $\begin{array}{r}171 \\
(53.6 \%)\end{array}$ & $\begin{array}{r}139 \\
(43.6 \%)\end{array}$ & $\begin{array}{c}9 \\
(2.8 \%)\end{array}$ & 0 & 0 & 1 & 1 \\
\hline 地 & 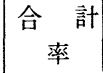 & $\begin{array}{c}1,194 \\
3.3 \%\end{array}$ & $\begin{array}{c}1 \\
0.08 \%\end{array}$ & $\begin{array}{c}3 \\
0.3 \%\end{array}$ & $\begin{array}{c}15 \\
1.3 \%\end{array}$ & $\begin{array}{r}62 \\
5.2 \%\end{array}$ & $\begin{array}{r}1,113 \\
93.2 \%\end{array}$ & $\begin{array}{l}1,152 \\
96.5 \%\end{array}$ & $\begin{array}{r}41 \\
3.4 \%\end{array}$ & $\begin{array}{c}1 \\
0.1 \%\end{array}$ & $\begin{array}{r}572 \\
48.0 \%\end{array}$ & $\begin{array}{r}581 \\
48.7 \%\end{array}$ & $\begin{array}{c}37 \\
3.1 \%\end{array}$ & $\begin{array}{c}3 \\
0.3 \%\end{array}$ & 1 & 4 & 2 \\
\hline
\end{tabular}


衛生環境とか，母親の育児知識を含めた生活家庭環境 等が関係しているのかも知れない（表一 7 )。

(3) 小括および考察

a) 圖, 䢑いずれも出生率は同じで，県平均よりや や高いが，周産期死亡率高低との重要な関連はな いとしても新興発展地域であるといえよう。

b ) 圖，四いずれも周産期死亡率高低と，乳児およ び新生児死亡率高低との関連はあるよらである。

c）病院出生は県北に比べて少なく, 圖では, 診療 所出生とほぼ五分五分である。园については，出 生児数が少なく固々の考察対象となり難い。 d）人工死産率は圖では, 8.7 ときわめて低く,低で, 県平均並である。圖地域は, 新興開発居住地域と の関連があるのかも知れない。

e ）満28週未満の自然死産率は，圖，低いずれも同 程度にきわめて高く，医療環境との関連として考 えたい。

f ) 県南東部, 全周辺町村には, 産婦人科, 小児科 併設病院は 7 か所のみで, 軽装備 NICU 所有病院 は 1 か所あるにしても, 重装備 NICU 中核病院は ない。県北全周辺市町村と著しい違いである。

3 ) 県南中部地域 (5 市町村): (表- 8 , 表- 9 )

表 8.土浦保健所（県南中部）管轄（58年度）

\begin{tabular}{|c|c|c|c|c|c|c|c|c|c|c|c|c|c|c|c|c|}
\hline \multirow{3}{*}{ 市町 村 } & \multirow{3}{*}{\multicolumn{2}{|c|}{$\begin{array}{c}\text { 人口出生数 } \\
\text { (率) } \\
\text { (S.58.10.1) (人口千対) }\end{array}$}} & \multirow{3}{*}{\multicolumn{3}{|c|}{ 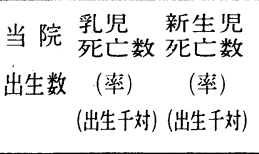 }} & \multicolumn{5}{|c|}{ 死 } & \multicolumn{4}{|c|}{ 周産期死亡（）：当院例 } & \multirow{2}{*}{\multicolumn{2}{|c|}{$\begin{array}{l}28 \text { 週未満の } \\
\text { 自然死産 }\end{array}$}} \\
\hline & & & & & & \multirow{2}{*}{\multicolumn{2}{|c|}{ 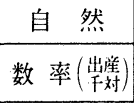 }} & \multirow{2}{*}{\multicolumn{2}{|c|}{ 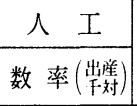 }} & \multirow{2}{*}{$\begin{array}{l}\text { 不 } \\
\text { 明 }\end{array}$} & \multirow{2}{*}{ 総数 } & \multirow{2}{*}{$\begin{array}{l}\text { 後期 } \\
\text { 死産 }\end{array}$} & \multirow{2}{*}{$\begin{array}{l}\text { 早期新生 } \\
\text { 児死亡 }\end{array}$} & \multirow{2}{*}{ 率 } & & \\
\hline & & & & & & & & & & & & & & & \multicolumn{2}{|c|}{ 数 率( (背䞍) } \\
\hline 茨城県総数 & $2,659,674$ & $\begin{array}{r}35,412 \\
(13.3) \\
\end{array}$ & 962 & $\begin{array}{c}289 \\
(8.2) \\
\end{array}$ & $\begin{array}{l}189 \\
(5.3) \\
\end{array}$ & 913 & 24.8 & 535 & 14.5 & 5 & $\begin{array}{c}405 \\
(10)\end{array}$ & $\begin{array}{r}252 \\
(5)\end{array}$ & $\begin{array}{r}153 \\
(5) \quad(\end{array}$ & $\begin{array}{l}11.4 \\
(10.3)\end{array}$ & 661 & 17.9 \\
\hline $\begin{array}{l}\text { 土浦保健所 } \\
\text { 管 轄 } \\
\end{array}$ & $\begin{array}{c}193,744 \\
(7.3 \%) \\
\end{array}$ & $\begin{array}{r}2,323 \\
(12.0) \\
\end{array}$ & 388 & $\begin{array}{c}13 \\
(5.6)\end{array}$ & $\begin{array}{c}6 \\
(2.6) \\
\end{array}$ & 60 & 24.6 & 54 & 22.2 & 0 & $\begin{array}{r}21 \\
(2) \\
\end{array}$ & $\begin{array}{r}16 \\
(2) \\
\end{array}$ & $\begin{array}{r}5 \\
(0) \\
\end{array}$ & $\begin{array}{c}9.0 \\
(7.7) \\
\end{array}$ & 44 & 18.1 \\
\hline 土 浦 市 & 116,864 & $\begin{array}{l}1,409 \\
(12.1)\end{array}$ & 235 & $\begin{array}{c}9 \\
(6.4)\end{array}$ & $\begin{array}{c}3 \\
(2.1)\end{array}$ & 38 & 25.7 & 31 & 21.0 & 0 & $\begin{array}{l}13 \\
(1)\end{array}$ & $\begin{array}{r}10 \\
(1)\end{array}$ & $\begin{array}{r}3 \\
(0)\end{array}$ & 9.2 & 28 & 18.9 \\
\hline 美 浦 村 & 13,865 & 158 & 28 & 0 & 0 & 4 & 24.1 & 4 & 24.1 & 0 & $\begin{array}{r}2 \\
(0)\end{array}$ & $\begin{array}{r}2 \\
(0)\end{array}$ & $\begin{array}{r}0 \\
(0)\end{array}$ & 12.7 & 2 & 12.0 \\
\hline 出 島 村 & 17,965 & 181 & 63 & $\begin{array}{c}2 \\
(11.0)\end{array}$ & $\begin{array}{c}1 \\
(5.5)\end{array}$ & 4 & 21.1 & 5 & 26.3 & 0 & $\begin{array}{r}1 \\
(1)\end{array}$ & $\begin{array}{r}1 \\
(1)\end{array}$ & $\begin{array}{r}0 \\
(0)\end{array}$ & 5.2 & 3 & 15.8 \\
\hline 新 治 村 & 8,920 & 103 & 17 & $\begin{array}{c}1 \\
(9.7)\end{array}$ & $\begin{array}{c}1 \\
(9.7)\end{array}$ & 3 & 27.5 & 3 & 27.5 & 0 & $\begin{array}{r}2 \\
(0)\end{array}$ & $\begin{array}{r}1 \\
(0)\end{array}$ & $\begin{array}{r}1 \\
(0)\end{array}$ & 19.4 & 2 & 18.3 \\
\hline 阿 見 町 & 36,130 & 472 & 45 & $\begin{array}{c}1 \\
(2.1)\end{array}$ & $\begin{array}{c}1 \\
(2.1)\end{array}$ & 11 & 22.3 & 11 & 22.3 & 0 & $\begin{array}{r}3 \\
(0)\end{array}$ & $\begin{array}{r}2 \\
(0)\end{array}$ & $\begin{array}{r}1 \\
(0)\end{array}$ & 6.3 & 9 & 18.2 \\
\hline
\end{tabular}

表 9.土浦保健所 (県南中部) 管轄 (58年度)

\begin{tabular}{|c|c|c|c|c|c|c|c|c|c|c|c|c|c|c|c|c|}
\hline \multirow[b]{2}{*}{ 市町村 } & \multirow{2}{*}{\begin{tabular}{|l|} 
出生児 \\
出生 \\
総 数 \\
\end{tabular}} & \multicolumn{5}{|c|}{ 出 生 览 体 重 } & \multicolumn{3}{|c|}{ 出生の立会者 } & \multicolumn{5}{|c|}{ 出 産 場 所 } & \multirow{2}{*}{\multicolumn{2}{|c|}{\begin{tabular}{|l} 
産婦人和 \\
病院・誩 \\
療所の数
\end{tabular}}} \\
\hline & & $\begin{array}{l}1,000 \mathrm{~g} \\
\text { 未 満 }\end{array}$ & $\begin{array}{l}1,000 \sim \\
1,499 \mathrm{~g} \\
\end{array}$ & $\begin{array}{l}1,500 \sim \\
1,999 \mathrm{~g}\end{array}$ & $\begin{array}{l}2,000 \sim \\
2,500 \mathrm{~g}\end{array}$ & \begin{tabular}{|l}
$2,501 \mathrm{~g}$ \\
以 5.
\end{tabular} & 医師 & 助産婦 & その他 & 病院 & 診療所 & 助産所 & 自宅 & その他 & & \\
\hline $\begin{array}{l}\text { 茨 城 県 } \\
\text { 総数 (率) }\end{array}$ & 36,412 & $\begin{array}{c}39 \\
(0.1 \%)\end{array}$ & $\begin{array}{c}119 \\
(0.3 \%)\end{array}$ & $\begin{array}{c}294 \\
(0.8 \%) \\
\end{array}$ & $\begin{array}{l}1,609 \\
(4.5 \%)\end{array}$ & $\begin{array}{l}33,351 \\
(94.3 \%)\end{array}$ & $\begin{array}{l}34,310 \\
(96.9 \%)\end{array}$ & $\begin{array}{l}1,096 \\
(3.1 \%) \\
\end{array}$ & 620 & $\begin{array}{l}11,719 \\
(33.0 \%)\end{array}$ & $\begin{array}{l}14,260 \\
(40.3 \%) \\
\end{array}$ & $\begin{array}{l}915 \\
(2.6 \%)\end{array}$ & 95 & 25 & $\begin{array}{l}\text { 病 } \\
\text { 院 }\end{array}$ & \begin{tabular}{|l} 
診 \\
療 \\
所 \\
\end{tabular} \\
\hline $\begin{array}{l}\text { 土浦保健所 } \\
\text { 管轄 (率) }\end{array}$ & 2,323 & $\begin{array}{c}1 \\
(0.04 \%)\end{array}$ & $\begin{array}{c}7 \\
(0.3 \%) \\
\end{array}$ & $\begin{array}{c}26 \\
(1.1 \%) \\
\end{array}$ & $\begin{array}{r}117 \\
(5.06 \%) \\
\end{array}$ & $\begin{array}{r}2,172 \\
(93.5 \%) \\
\end{array}$ & $\begin{array}{r}2,310 \\
(99.4 \%) \\
\end{array}$ & $\begin{array}{r}13 \\
(0.6 \%)\end{array}$ & 0 & $\begin{array}{c}1,307 \\
(56.3 \%)\end{array}$ & $\begin{array}{r}1,005 \\
(43.3 \%)\end{array}$ & $\begin{array}{c}8 \\
(0.3 \%)\end{array}$ & 3 & 0 & 6 & 13 \\
\hline 土浦市(率) & 1,409 & 0 & $\begin{array}{c}5 \\
(0.4 \%)\end{array}$ & $\begin{array}{c}17 \\
(1.2 \%)\end{array}$ & $\begin{array}{r}68 \\
(4.8 \%)\end{array}$ & $\begin{array}{r}1,319 \\
(93.6 \%)\end{array}$ & $\begin{array}{r}1,402 \\
(99.5 \%)\end{array}$ & $\begin{array}{r}7 \\
(0.5 \%)\end{array}$ & 0 & $\begin{array}{r}779 \\
(55.3 \%)\end{array}$ & $\begin{array}{r}623 \\
)(44.2 \%)\end{array}$ & 4 & 3 & 0 & 5 & 11 \\
\hline 美浦村(率) & 158 & 1 & 1 & 0 & 8 & 148 & 154 & 4 & 0 & $\begin{array}{r}84 \\
(53.2 \%)\end{array}$ & $\begin{array}{r}72 \\
(45.6 \%)\end{array}$ & 2 & 0 & 0 & 0 & 2 \\
\hline 出島村 (率) & 181 & 0 & 1 & 3 & 5 & 172 & 181 & 0 & 0 & $\begin{array}{r}115 \\
(63.5 \%)\end{array}$ & $\begin{array}{r}66 \\
(36.5 \%)\end{array}$ & 6) & 0 & 0 & 0 & 0 \\
\hline 新治村(率) & 103 & 0 & 0 & 0 & 3 & 100 & 102 & 1 & 0 & $\begin{array}{r}39 \\
(37.9 \%)\end{array}$ & $\begin{array}{r}63 \\
(61.1 \%)\end{array}$ & 1 & 0 & 0 & 0 & 0 \\
\hline 阿見町(率) & 472 & 0 & 1 & 6 & 33 & 432 & 471 & 1 & 0 & $\begin{array}{r}290 \\
(61.4 \%)\end{array}$ & $\begin{array}{r}181 \\
(38.3 \%)\end{array}$ & 1 & 0 & 0 & 1 & 0 \\
\hline
\end{tabular}


（1）出生率，乳児死亡率，新生児死亡率，周産期死 - 9)。

亡率, 死産率

人口規模は $7.3 \%$, 検討 3 地区のなかでは一番多い。 出生率は，12.0で県平均（13.3）よりやや低い。乳児 死亡率および新生児死亡率はそれぞれ5.6,2.6で, 県 平均 $(8.2,5.3)$ よりきわめて低い。周産期死亡率は 9.0 と全国平均（9.3）より低く，またこの地域におけ る当院出産の当院の周産期死亡率はさらに低く7.7で ある。満28週未満の自然死産率は, 18.1でほぼ県平均

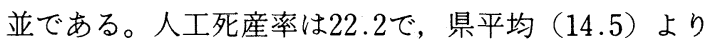
高く, 県北低地域（22.7）並である（表-8）。

（2）出生児体重, 出産場所

未熟児出生率は, 県平均レベルであるが, 土浦市の みに限定すると, その数はきわめて多い。この地区は, 病院 6 (産婦人科, 小児科併設病院 3 ケ所, そのすべ てが, 総合大病院, 産婦人科病院 3 ケ所), 診療所 13 , 小児科抏よび内科併設診療所 18 , と, また重装備 NICU 中核病院が当院であり, 非常に医療環境に恵まれてい るので, 出産場所は, 病院 $56.3 \%$, 診療所 $43.3 \%$ となっ ている。また, 助産所出生は $0.3 \%$ ときめて少ない(表
(3) 小括および考察

小括としてまとめるまでもないが，この地域ほど， すべての調査結果が最高であることと, 医療環境がき わめて恵まれていることとの関連が, データーとして 明瞭に結びついている。

人工死産が県北低地域と同率に高く，いずれも，生 活経済面からの理由が多いのであろらが，その意味合 は多少異なるものと思う。この地域は, 主に市街地周 辺地区といらこと, 県北低地域は過疎農村地区が比較 的多いといら差から考察する必要があろら。

4 ) 当院の出産児数, 出産児体重, 死産児数, 早期 新生览死亡数および死因：（表-10）

周産期死亡率高低を厳密に検討するには、死亡例を 一つ一つその死因を含めて調査して，その主因は何か を考察する必要がある。しかし，それはなかなか不可 能な問題があるので，当院例（昭和 58 年度）の上記項 目について解析し, 前記 3 地域の検討対照資料とした い。

(1) 出生児

表10. 当院, 出産児数, 死産児数, 早期新生児死亡数及び死因（昭和58年度）

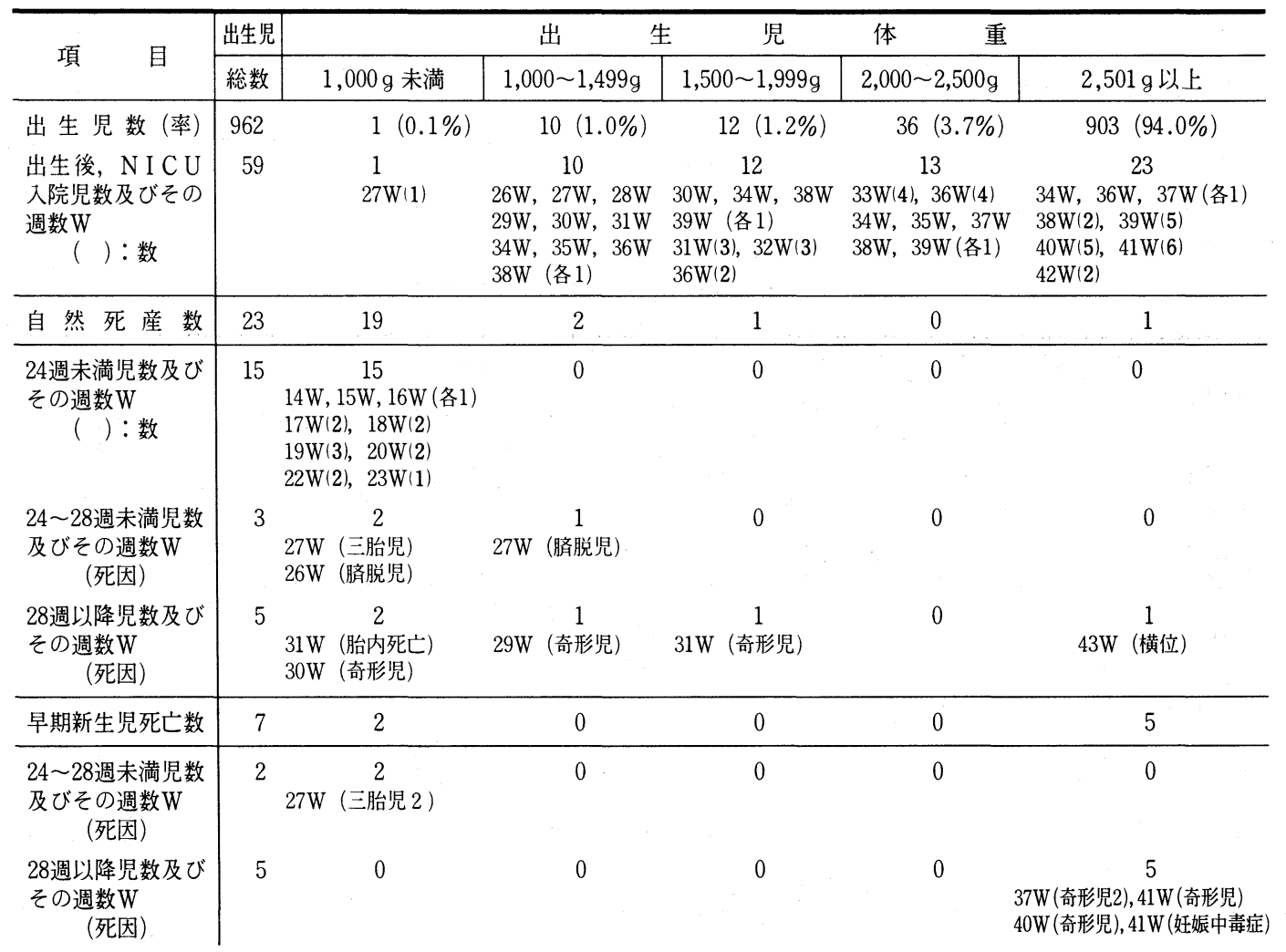


962名出生児のうち，59名（6.1\%）が NICU 入院と なっている。2,000 g 未満の未熟児23名全例入院はい らまでもないが，2,501 g 以上の正常体重出生児でも， ハイリスク分婏の場合, 23 名 (2.5\%) が NICU 入院加 療となっている。NICUの重要性は低体重出生児の加 療はいうまでもないが，八イリスク分婏，正常体重出 生児の加療にとっても重要であることを銘記すべきも のと思う。もし，NICUの設備がなかったならば, NICU 入院児のらち, 何名かは, 早期新生児死亡となっ ていたかも知れない12)。

(2) 死産児，死亡児

自然死産数 23 名中, 15 例が満 24 週未満の超未熟児で あり，現在では，なおこの段階の生児を得られるのは きわめて少ない。満24週から満28週未満児の死産児 3 名の死因は, 臍脱児之三胎児の超未熟児となっている。

周産期死亡に関係する満28週以降の死産児は 5 名 で，その死因は奇形児 3 名，超未熟児の胎内死亡児 1 名の計 4 名は止むを得ない, さけられない死産である が, 横位が死因である 43 週正常体重緊急帝切死産児は, 分婏監視いかんによっては生児となり得る症例と思

表11. 出産児平均体重と在胎週数

\begin{tabular}{l|c|c|c}
\hline \multirow{2}{*}{ 調査種別 } & \multicolumn{2}{|c|}{ 周 産 期 死 亡 群 } & 疫学調查群 \\
\cline { 2 - 5 } 項目 & 57 年 & 58 年 & 58 年 \\
\hline 出産児平均体重 & $2090 \mathrm{~g}$ & $2278 \mathrm{~g}$ & $3200 \mathrm{~g}$ \\
(標準偏差) & $(966)$ & $(930)$ & $(410)$ \\
在 胎 週 数 & $\begin{array}{c}34.3 \text { 週 } \\
\text { (標準偏差) }\end{array}$ & $\begin{array}{c}33.6 \text { 週 } \\
(6.4)\end{array}$ & $\begin{array}{c}39.8 \text { 週 } \\
(6.0)\end{array}$
\end{tabular}

日本産科婦人科学会, 茨城地方部会調查 (60年 3 月)

表12. 当院の周産期死亡率（28週以降）

\begin{tabular}{|c|c|c|c|c|c|c|}
\hline 年 & 度 & 生産数 & 死産数 & 出産数 & $\begin{array}{l}\text { 早 期 } \\
\text { 新生芘 } \\
\text { 死亡数 }\end{array}$ & $\begin{array}{l}\text { 周産期 } \\
\text { 死亡率 }\end{array}$ \\
\hline \multicolumn{2}{|c|}{$\begin{array}{l}50 \text { 年 53年 } 5 \text { 月 } \\
\text { N I C U 設置前 }\end{array}$} & $\begin{array}{l}1912 \\
(3)\end{array}$ & $\begin{array}{l}25 \\
(2)\end{array}$ & $\begin{array}{c}1937 \\
(8)\end{array}$ & 13 & 19.8 \\
\hline \multicolumn{2}{|c|}{$\begin{array}{l}57 \text { 年 } 58 \text { 年 } \\
\text { N I C U 設置後 }\end{array}$} & $\begin{array}{l}1957 \\
(6)\end{array}$ & $\begin{array}{c}7 \\
(2)\end{array}$ & $\begin{array}{l}1964 \\
(10)\end{array}$ & $\begin{array}{l}12 \\
(5)\end{array}$ & 9.7 \\
\hline
\end{tabular}

表13. 当院 5 年間（57 61 年）の体重別 周産期死亡数 (28週以降)

\begin{tabular}{c|c|c|c|c|c}
\hline $\begin{array}{l}1000 \mathrm{~g} \\
\text { 末 満 }\end{array}$ & $\begin{array}{c}1001 \sim \\
1500 \mathrm{~g}\end{array}$ & $\begin{array}{c}1501 \sim \\
2000 \mathrm{~g}\end{array}$ & $\begin{array}{l}2001 \sim \\
2500 \mathrm{~g}\end{array}$ & $\begin{array}{l}2501 \mathrm{~g} \\
\text { 以 }\end{array}$ & 計 \\
\hline 7 & 10 & 9 & 5 & 26 & 57
\end{tabular}

全出産数：4664
ら。また満28週以降の早期新生児死亡例は 5 名あるが, いずれも正常体重児で, 奇形児 4 名は止む得ないとし ても，妊娠中毒症原因の死亡例は，管理いかんによっ ては，生児になり得たであろら（表-10）。

（3）小括および考察：(表-11，表-12，表-13，表 -14)

周産期死亡例の原因から考察すると, 胎児奇形, 超 未熟児等のように避けられない症例と, 妊娠分婏管理 監視いかんによっては避けられ得る症例とがあるわけ で, 未熟児出生児の管理を含めて, 後者の医療機関側 の因子（対応いかん）が，周産期死亡率向上の大きな ポイントである。

周産期死亡群では, 低出産体重児および早産児に多 いことは, 日本産科婦人科学会茨城地方部会の調查6) によっても明らかである（表-11）。したがって，その ハイリスク分婏による，ハイリスク出生児には NICU が欠かせない。

当院では, 昭和53年 6 月に NICU を設置したのであ るが，その設置前後で，周産期死亡率が，19.8から 9.7 と著しく改善されている ${ }^{10)}$ (表-12)。特に低出産児に対 して, その傾向にある ${ }^{10)}($ 表-14)。しかし, 周産期死亡 児は低出産児のみではない。当院最近 5 年間の体重別 周産期死亡数をみても(表-13), $2,000 \mathrm{~g}$ 以下の未熟児 が26名, $2,501 \mathrm{~g}$ 以上の正常体重児が26名と数として はかなり多いことから，ハイリスク妊娠分婏に対する

表14. 周産期死亡数 (28週以降)

\begin{tabular}{|c|c|c|c|c|c|c|}
\hline \multirow[b]{2}{*}{ 年 $_{\text {度 }}$} & \multicolumn{3}{|c|}{ 周産期死亡数 } & \multicolumn{3}{|c|}{ 全出産数に対する率 $(\%)$} \\
\hline & \multicolumn{3}{|c|}{$\begin{array}{cc}50 \sim 53 \text { 年 } & 54 \sim 58 \text { 年 } \\
\text { (NICU設置前) } & \text { (設置後) }\end{array}$} & \multicolumn{3}{|c|}{$\begin{array}{c}50 \text { ～53年 } \\
\begin{array}{c}54 \sim 58 \text { 年 } \\
\text { (NICU設置前) }\end{array} \text { (設置後) }\end{array}$} \\
\hline $2,000 \mathrm{~g}$ 未満 & \multicolumn{3}{|r|}{37} & & 1.4 & 0.8 \\
\hline $\begin{array}{l}2,000 \mathrm{~g} \sim \\
2,500 \mathrm{~g} \text { 未佩 }\end{array}$ & \multicolumn{2}{|c|}{8} & 6 & & 0.3 & 0.1 \\
\hline $2,500 \mathrm{~g}$ 以上 & \multicolumn{2}{|c|}{5} & 16 & & 0.2 & 0.4 \\
\hline 計 & \multicolumn{2}{|c|}{45} & 59 & & 1.9 & 1.3 \\
\hline & \multicolumn{4}{|c|}{$\begin{array}{l}50 \sim 53 \text { 年 ( } 4 \text { 年間 }) \\
54 \sim 58 \text { 年 }(5 \text { 年間) }\end{array}$} & \multicolumn{2}{|l|}{$\begin{array}{l}2329 \text { 名 } \\
4588 \text { 名 }\end{array}$} \\
\hline
\end{tabular}

表15. 当院未熟児センター入院患者数 (56年～61年)

\begin{tabular}{c|c|c}
\hline $\begin{array}{c}\text { 他医より転送 } \\
\text { 入院新生児 }\end{array}$ & $\begin{array}{c}\text { 当院産婦人科より } \\
\text { 入院新生览 }\end{array}$ & 合 計 \\
\hline $\begin{array}{c}579 \\
(55 \%)\end{array}$ & $\begin{array}{c}479^{*} \\
(45 \%)\end{array}$ & 1058
\end{tabular}

*乙の中 59 名が母体搬送出生児 (59年 61年) 
表16. 昭和58年度当院分娩 (24週以降)

患者, 市町村別数 (判明者のみ)

県内 49 市町村：883人 $(93.5 \%)$

県外

\begin{tabular}{c|l}
\hline 人 数 & \multicolumn{1}{|c|}{ 市 町 村 (県内) } \\
\hline 237 & 土浦市 \\
103 & 千代田村 \\
$50 \leqq<100$ & 出島村, 石岡市 \\
$30 \leqq<50$ & (旧)筑波町, 阿見町, (旧) 桜村, \\
& 八郷町 \\
$10 \leqq<30$ & 牛久市, 美浦村, 新治村, \\
& (旧)豊里町, (旧)谷田部町, \\
& (旧)大穂町, 江戸崎町, \\
& 美野里町, 竜ヶ崎市, \\
& 石下町, 茎崎町 \\
$1 \leqq<10$ & 30 市町村
\end{tabular}

医療機関側の管理体制の充実と同時に，ハイリスク分 婏正常体重児の生存にも，NICUは欠くことができな い成績データーとなっている。

5 ）当院の NICU の現状：（表-15）

当院は，県南中心部の新生児救急中核指定病院であ るが，当院最近 6 年間の NICU 入院新生児数をみる 之, 他医院分婏転送新生児が579名 (55\%), 当院分婏 転科新生児が479名 (45\%) で, 新生児転送入院児がや や多いという結果である。（昭和56年～昭和 61 年）

昭和59年より昭和61年までの 3 年間をみると, 新生 児転送入院児が 277 名 $(50 \%)$ で，当院分娩転科新生児 が285名 (50\%) で，このうち59名 (23.5\%) が母体搬 送出生児である。その収容にも拉のずと限界があるの が現状である。

6 ) 当院出産妊婦の住居範囲：(表-16, 図-1)

当院産婦人科出産妊婦の住居範囲を昭和 58 年度 945 名(判明者のみ)で調べると, 県内が 49 市町村で $93.5 \%$, 里帰り分婏の県外居住者が $6.5 \%$ で，しかも図-1 線の枠内のうち, 土浦市, 石岡市, 千代田村, 出島村 で計463名(49\%)であり，枠内全部の19市町村では791 名 $(83.7 \%)$, 枠外の県内市町村は30に散在する92名 (9.7\%) である。

その周産期死亡例居住者は満24週以降で15名（満28 週以降では10名）全例が県内で, 太線枠外居住者は, そのうち 6 名であった。

この解析結果から推測できることは，本論文の基礎 となる市町村別周産期死亡率は, 当然個々の医療機関 別の周産期死亡率とは意味合が違うのであるから， 個々の市町村の周産期死亡率高低は，主にそれぞれの
市町村周辺地域に存在する出産医療機関別周産期死亡 率の総和を，括の拈のの市町村が分配した結果として の高低値を示しているとみるべきであろう。

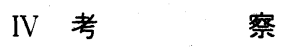

1 ）周産期死亡率について

周産期死亡率は地域母子保健の水準を示す代表的な 指標のひとつであることは異論のないところである が，本論文の基礎となる市町村別母子衛生指標からの 周産期死亡率高低より，単純にそれぞれの市町村の母 子保健水準の高低を云々することは, 慎重にすべきで あろう。広大な全国平均または県平均レベルで死亡率 を論ずることは別であるが, 狭盒な市町村レベルでは, その率に影響を与える母集団 (出生数) が少ないし, 必ずしもその市町村内の医療機関での出産とは限って いない。すなわち, 出産者の居住地と出産医療機関の 住所が異なる場合，その周産期死亡を含めた出産およ び死亡届は, 出産者の居住地市町村に届けることに なっているからである。

したがって, 個々の医療機関から調查する周産期死 亡率は，その機関であつかった地域の母子保健水準を 示すといらよりは，その機関自身の母子保健水準，む 乙万管理能力水準を示す医療機関周産期死亡率といら ベきであり, 市町村別のあるいは, 衛生統計レベルの 周産期死亡率とは，その意味合いが異なることも当然 念頭に入れて考察しなければいけない。

しかし，(III-2-6 )) で述べたように，当院出産 者の住居範囲から推察すると, 県内が $93.5 \%$, 里帰り 分婏の県外が $6.5 \%$ で，土浦市周辺地域が $49.0 \%$ (土浦 市のみは25\%), その他のかなり遠方になる県南東西部 および県北の市町村は 30 に散在し，約 $9.7 \%$ ，また周産 期死亡例は15例（満24週以降）の全例が県内で, 土浦 市周辺地域以外は，そのうち6 例であった。この調査 より推測すれば, 個々の市町村の周産死亡率高低は, 主にそれぞれの市町村周辺地域に存在する出産医療機 関別周産死亡率の総和を因子として扮の扮のの市町村 が分配した結果と，それぞれの市町村自身の環境因子 および，その市町村に住んでいる妊婦自身の問題因子 等を示す総合結果としての高低值を示しているとみる ベきであろう。したがって，極言すれば，茨城県の周 産期死亡率を向上させるためには，まずもって出産す る各医療機関がそれぞれ医療機関としての周産期死亡 率を向上させることであろう。それには, 重装備 NICU 設備の中核病院を中心にした, 各医療機関間とのネッ トワークを作ることと，そことの新生児および母体搬 送の方法を解決させることが肝要であろら。 


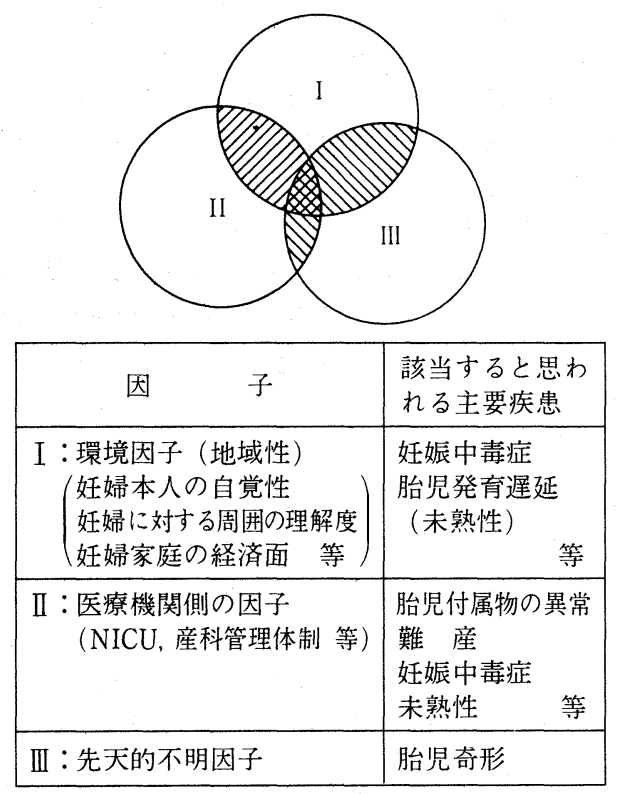

図 2.周産期死亡の諸因子

しかし，また医療機関としての周産期死亡率を向上 させるにも，限界があることも事実である。仮に最良 最高の妊婦分婏管理体制で対処したとしても，周産期 死亡の原因いかんによっては（例之ば，重症奇形児， 超未熟児等), 重装備 NICU 所有中核病院でも生児は 得られにくい。

周産期死亡率を向上させるにはもちろん医療環境因 子のみでなく，その他の因子も当然あるが，まず出産 する場所で 1 例でも死産, 早期新生児死亡を減少させ ない限り, 市町村別周産期死亡率の改善はあり得ない であろう。

2 ) 周産期死亡の因果関係について: (図-2）9

複雑で決定的な結論は出ないのであるが, 死亡児に ついてみると, 低出産体重児が多く, 茨城県に特有な ものではないが, その死因は, 未熟性, 呼吸異常がか なりな数を占めていることは, 日本産科婦人科学会, 周産期管理登録委員会報告8/で明らかであり, また当 院の報告9)でも同様である。したがって, その対応に は, NICUの重要性から考えないわけにはいかない。

周産期死亡率高率地域あるいは低率地域と医療機関 （特に NICU 設置機関）との関連を厳密に検討するに は, 各市町村での周産期死亡例を一つ一つ, その出産 医療機関の種類㧍よび場所, 死産, 死亡の要因疾患お よびそれらの体重等をくまなく調査して, その主因は 何かを考察する必要があるが, 県内各医師会および市 町村役場の了解を得るのはきわめて難題である。
また，周産期死亡の原因の因子は図一 2 のように複 雑で, 医療機関側の因子, 妊婦自身の生活環境因子, また，自然環境因子，先天異常因子等，さまざまであ り, それらと各市町村地域差との関連性は簡単には解 明し難い。

全国的にみても，また県内および当院でも，周産期 死亡原因の第 1 位は, 毎年常に胎児奇形死亡であ $3^{8,9)}$ 。その奇形死亡の原因は先天異常因子が圧倒的に 多( ${ }^{8)}$ のであるが, この解決には, 現在の医学, 医療の レベルでは，まだまだ防ぎょらがないのである。早期 発見, 早期出産にするのが精一杯の現状である。

日産婦茨城地方部会の妊婦度学調査 ${ }^{6}$ によると, 死 亡児の母側の生活環境にも問題があると指摘されてい る。しかし，本論文では主に医療機関側の因子，特に NICU 設置機関の点を中心にして検討報告したもので あり, 当院での NICU 設置前後の改善成績結果 ${ }^{101}$ から みて, その妥当性を普遍して, 県単位でも同じであろ らと推論したい。

3) NICU の県内設置状況

当病院では, 昭和53年 6 月に, NICUを設置したの であるが, 茨城県における新生児救急医療システムは, 立ち遅れており, 昭和 60 年 7 月に県立こども病院が開 設され，昭和62年 7 月にこのシステムが県行政の立場 から整備され, 県内を 3 ブロックと地域割りとし, 県 立こども病院を中心に県北地域は日立総合病院, 県南 地域については当病院と, 3 か所の中核病院を基幹に 新生児医療を整備運用されることになったばかりであ る。

北海道北地区では，新生児医療の地域化によってい ろいろ問題はあるが，効果をあげていると上田 ${ }^{1}$ は発 表している。しかし, 定床ベッド数は, 当県では, 計 60 床（こども病院 25 床, 日立総合病院 15 床, 土浦協同 病院20床) で, 実際の稼動は50床くらいであり，人口 数約 270 万人 (昭和 60 年度), 出生数約 3.3 万人 (昭和 60 年度）の茨域県にとっては, ベッド数としてはまだ著 しい不足である。

静岡県立こども病院の志村 ${ }^{4}$ は，人口100〜150万人 に, 30〜40木㦿の充分な設備とスタッフをそろえた新生 児センターが設立され，また，その地域のいかなる場 所で何時生まれようとただちにセンターに収容される よらな搬送システムが併存すれば，必ずその地域の新 生児死亡率, 周産期死亡率は減じ, また, 重症心身障 害児の発生防止も可能にすると, 発表している。静岡 県では, 昭和 52 年 4 月から県西部㧍よび中部に $30 \sim 40$ 㦿の新生児センターが開設され，その後東部地区の開 設も含めて, 現在では著しい新生児医療の成果をあげ 
ている。ちなみに, 静岡県の 3 センターのベッド数 93 床, 昭和 60 年度の静岡県人口 358 万人, 出生数約 4.4 万 人である。

4) 以上三つの考察点から本論文の調查結果および 成績を解析すると, 周産期死亡率の高い県南東部は概 して高度設備医療機関としての NICUの恩恵に浴さ れにくい所であることが明白であり，今日搬送システ ムが充実しているとはいえないので，前記地域内に重 装備 NICU 医療施設を供えた中核病院を配備するこ とが焦眉の急であり，そのことが，茨城県内の周産期 死亡率の地域格差を改善する最短な道であると推論し たい。

また，周産期死亡率低率な所が多い県北の中に， NICU 扣よびその他の医療環境が周辺地区に比較的多 く存在しているのにかかわらず, 高率地域が 3 町村存 在しているが，恐らく新生児あるいは母体搬送等の不 備な問題があるのかも知れないが，その理由について は, 死亡原因の内容等を調查しない限り判明し難い。

現在および，今後の課題として，新生児および母体 搬送の検討, 勤務扣よび開業産科医と, 小児科医（新 生児科医）との密な連携と, 生涯修練が要望されるこ とは当然であろう。

$$
\mathrm{V} \text { ま め }
$$

茨城県の周産期死亡率が全国平均より常に悪いの は, 重装備 NICU 設置医療機関が県内 3 か所と, その ベッド数の点からみて, やや少ないことによるもので ある。

また, 県内92市町村別の周産期死亡率を検討すると， 格差が明瞭で, 県南東部に高率な町村が遍在している。 その地域周辺は比較的県内でも出生率がやや高く, 農 村地区を周囲に多く含んだ新興発展町村地域（鹿島工 業開発地域) であると同時に, 産婦人科病院および診
療所がやや少なく，中核となる 3 か所の NICU 設置医 療機関に遠く，新生児搬送システムが不充分なことも 含めて NICU の恩恵に浴されにくい地域である。

当院での NICU 設置前後の成績, すなわち, 設置前 の周産期死亡率が 19.8 から設置後 9.7 と改善されてい る結果からみると, 普遍して茨城県の周産期死亡率を 向上させるには, 重装備 NICU 医療施設が増設される ことによって同じことが県単位でも実現し得ると推論 したい。特に, 県南東部に配備することが焦眉の急で あろら。

本論文の要旨は, 昭和 62 年 7 月 26 日第 14 回関東農村医学会総会 にて発表した。

\section{文献}

1）上田大輔・他：北海道北地区に抢ける新生児医療の地域化の 効果の問題点, 日新生児学誌, 23(1): 282-287, 1987

2) 浅見政俊・他：母体搬送に打ける現状と問題点, 日産婦関連 会報, $46: 161,1987$

3）田所義晃・他：中規模施設での産婦人科救急の現状, 日産婦 関連抄表, $74: 115,1987$

4) 志村浩二：静岡県立こども病院における新生児医療，茨母衛 生誌, $3: 37,1983$

5 ）厚生省児童家庭局母子衛生課監修：母子衛生の主なる統計, 東京, 1986

6) 日本産科婦人科学会茨城地方部会: 茨城県周産期死亡実態 調査報告書, 茨城, 1985

7) 茨城県衛生部医務課：茨城県衛生統計年報, 茨城, 1983

8) 日本産科婦人科学会: 周産期管理登録委員会報告, 日産婦学 誌, 39(9) : 1683-1700, 1987

9 ）潤田嘉朗・他：周産期死亡原因の分析, 当院 9 年間の集計上 $\eta$, 日農医学誌, 35(5)：81-82, 1987

10）潤田嘉朗・他：当院における過去 9 年間の周産期死亡率の推 移, 日農医学誌, 34(3) : 496-497, 1985

11）茨城県医師会：会員名簿，茨城， 1986

12）潤田嘉朗・他：ハイリスク分婏での周産期生存例と死亡例と の検討, 日農医学誌, 35(3)：88-89, 1986 


\title{
Regional Disparities in Perinatal Mortality Rate in Ibaraki Prefecture
}

\author{
Yoshiro URUTA
}

Ibaraki Prefecture is noted for its high mortality rates among babies in the perinatal period. During 1984, 10. 9 of every 1,000 perinatal babies died, compared with the national average of 8. 7 . In the prefecture, however, there are considerably wide gaps in the survival odds of perinatal babies from region to region.

Statistics covering 92 cities, towns and villages in Ibaraki Prefecture showed that perinatal mortality rates during the period of $1979-83$ stood at 13.4 on the average. The average of the top 10 municipalities on the deathrate list was 22.7 , while that of the last 10 municipalities was 7.18 . The municipalities marking higher rates are concentrated in the southeastern part (6 regions) and western part (1 region) of the prefecture, and the municipalities marking lower rates are located in northern Ibaraki (6 places).

The reason for this uneven distribution remains to be seen. However, we have investigated into the situations of these municipalities in terms of the size of population, live birth rate, fatal mortality rate, infant mortality rate, neonatal mortality rate and early neonatal deaths. Furthermore, a survey was carried out on the number of deliveries in hospitals and weight of newborns in the northern, southeastern and southern/central parts of the prefecture.

It was found that only three medical institutions have NICU (intensive care unit for neonates) across the prefecture. This number is rather small considering the number of beds. This may be partly responsible for the high rate of perinatal mortality rate in Ibaraki Prefecture. The rate in our hospital, wich is located in the southern part of the prefecture, has dropped from 19.8 to 9.7 since a NICU was installed.

The present paper will also discuss other findings in the high perinatal mortality rate regions in southeastern Ibaraki Prefecture.

* Department of Obstetrics and Gynecology, Tschiura Kyodo Hospital. 